\title{
Merespon Perubahan Dalam Pemenuhan Kebutuhan Sumber Daya Manusia Di SMP Negeri 1 Pacet
}

\author{
Barnoto \\ ${ }^{1}$ Pascasarjana Institut Pesantren Kh. Abdul Chalim Pacet Mojokerto \\ e-mail: barnoto.ikhac@gmail.com
}

Submitted: 01-01-2020 Revised : 15-02-2020 Accepted: 03-03-2020

\begin{abstract}
Kepemimpinan adalah kemampuan untuk menciptakan perubahan yang paling efektif dalam perilaku kelompok: bagi yang lain dia adalah proses mempengaruhi kegiatan-kegiatan kelompok ke arah penetapan tujuan dan pencapaian tujuan. Fungsi kepemimpinan ialah: memadu, menuntun, membimbing, membangun, memberi atau membangunkan motivasi-motivasi kerja, mengemudikan organisasi, menjalin jaringan komunikasi-komunikasi yang baik, memberikan supervisi/pengawasan yang efesien, dan membawa para pengikutnya kepada sasaran yang ingin dituju, sesuai dengan ketentuan waktu dan perencanaan. Kebijakan yang dibuat oleh kepala SMP Negeri 1 Pacet dalam meningkatkan kinerja pendidik professional adalah dengan cara mengikutkan KKG workshop, pelatihan, aktif dalam kegiatan di sekolah baik yang diselenggarakan oleh Dinas Pendidikan Kota maupun LPMP. Kebijakan yang telah di buat dengan cara mengoptimalkan peran kepala sekolah sebagai pemimpin yang meliputi: Sebagai pendidik (Educator), Sebagai manager, Sebagai administrator, Sebagai supervisor, Sebagai pemimpin (leader), Sebagai innovator, dan Peran kepala sekolah Sebagai menejemen kurikulum sebagaimana termaktub pada peraturan menteri pendidikan nasional nomor 13 tahun 2007 tentang standar Kepala sekolah /Madrasah, yaitu kompetensi Kepribadian, Menejerial, Kewirausahaan, supervisi, dan kompetensi sosial.
\end{abstract}

Keywords: Kepemimpinan, Motivasi, Kompetensi

https:

How to Cite

Barnoto. (2020). Merespon Perubahan dalam Pemenuhan Kebutuhan Sumber Daya Manusia di Sekolah Manenegah Pertama. Munaddhomah: Jurnal Manajemen Pendidikan Islam, Volume 1 (1), 110.

\section{PENDAHULUAN}

Keberadaan pendidik bagi suatu bangsa, amatlah penting, terlebih-lebih bagi kelangsungan hidup bangsa di tengah-tengah lintasan perjalan zaman dengan teknologi yang semakin canggih dan segala perubahan serta pergeseran nilai yang cenderung memberi nuansa kepada kehidupan yang menuntut ilmu dan seni dalam kadar dinamika untuk dapat mengadaptasikan diri.

Semakin profesional para pendidik melaksanakan tugas dan fungsinya, semakin terjamin tercipta dan terbinanya kesiapan dan keandalan seseorang sebagai manusia pembangunan. Untuk dapat melaksanakan tugas dan fungsinya tersebut, maka seorang pendidik dituntut profesional. Dengan keprofesionalan yang dimiliki pendidik akan dapat melaksanakan tugas dan fungsinya tersebut dengan sebaik-baiknya. Sebagaimana yang dikemukan Uzer Usman bahwa, proses pembelajaran dan hasil belajar peserta didik sebagian besar ditentukan oleh peranan dan pendidik yang profesional. 
Pendidik yang profesonal akan lebih mampu menciptakan lingkungan belajar yang efektif dan akan lebih mampu mengelola kelasnya sehingga hasil belajar peserta didik berada pada tingkat optimal. ${ }^{1}$ Bahkan A. Malik Fadjar menyatakah bahwa "Al-thariqah ahammu min al-maddah walakinna al-muddaris ahammu min al-thariqah (metode lebih penting dari pada materi, tetapi pendidik lebih penting daripada metode). ${ }^{2}$ Karena itulah menurut Syafrudin Nurdin, "kepada pendidik-pendidik yang profesional masa depan bangsa dan negara dapat dipercaya." 3 Begitu juga dengan Abudin Nata yang menyatakan bahwa "keberhasilan pendidikan sebagian besar ditentukan oleh mutu profesionalisme seorang pendidik."

Dengan demikian jelaslah bahwa profesionalitas pendidik merupakan salah satu faktor yang menentukan keberhasilan kegiatan pembelajaran dan mutu pendidikan. Profesionalitas pendidik sangat penting dalam memajukan atau sebaliknya bisa juga menghancurkan pendidikan. Ketika pendidik benar-benar berlaku profesional dan dapat mengelola dengan baik, tentunya mereka akan semakin bersemangat dalam menjalankan tugasnya bahkan rela melakukan inovasi-inovasi pembelajaran untuk mewujudkan kesuksesan pembelajaran peserta didik. Namun, jika mereka kurang profesional, maka mereka justru bisa menjadi penghambat paling serius terhadap proses pendidikan. Untuk itu profesionalitas pendidik mutlak dimiliki setiap pendidik guna tercapainya tujuan pendidikan.

Pendidik yang profesional menurut Uzer Usman adalah orang yang terdidik dan terlatih dengan baik, serta memiliki pengalaman yang kaya di bidangnya. ${ }^{5}$ Sedangkan menurut Kunandar bahwa pendidik professional adalah pendidik yang dalam pelaksanaan tugas dan pengabdiannya ditandai dengan keahlian baik dalam materi maupun metode juga bertanggung jawab baik itu dalam tanggung jawab pribadi, sosial, intelektual, moral, dan spiritual. ${ }^{6}$ Dan menurut Hamzah B. Uno pendidik professional adalah pendidik yang memiliki berbagai kemampuan agar ia dapat melaksanakan tugas mengajarnya dengan berhasil.

Dengan demikian dapat disimpulkan bahwa yang dimaksud dengan pendidik professional adalah pendidik yang senantiasa menguasai bahan atau materi pelajaran yang akan diajarkan dalam interaksi belajar mengajar, serta senantiasa mengembangkannya kemampuannya secara berkelanjutan, baik dalam segi ilmu yang dimilikinya maupun pengalamannya. Dan profesionalitas pendidik ditunjukkan dari kemampuan atau keahlian yang dimiliki seorang pendidik yang professional. Sebagaimana yang dikemukakan Muhibbin Syah bahwa profesionalitas pendidik berasal dari kata sifat profession (pekerjaan) yang berarti sangat mampu melaksanakan pekerjaan. Dalam hal ini mampu melaksanakan pekerjaan sebagai pendidik. ${ }^{8}$

Berdasarkan beberapa pendapat tentang persyaratan pendidik professional tersebut, maka tugas seorang pendidik bukan lagi knowledge based, akan tetapi lebih bersifat competency based, yang menekankan pada penguasaan secara optimal komsep keilmuan dan perekayasaan yang berdasarkan nilai-nilai etika dan moral.

Profesionalitas seorang pendidik tidak terwujud dengan sendirinya, akan tetapi melalui perjuangan yang berat dan cukup panjang. Menurut T. Raka Joni ada enam cara dalam

\footnotetext{
${ }^{1}$ Moh. Uzer Usman, Menjadi Pendidik Profesional, (Bandung: Remaja Rosdakarya, 2001), h. 9

${ }^{2}$ Malik Fadjar, Holistika Pemikiran Pendidikan, (Jakarta: Raja Grafindo Persada, 2005), h. 188

${ }^{3}$ Syafruddin Nurdin dan Basyuruddin Usman, Pendidik Profesional dan Implementasi Kurikulum, (Jakarta: Ciputat Press, 2003), h. 20

${ }^{4}$ Abuddin Nata, Manajemen Pendidikan; Mengatasi Kelemahan Pendidikan Islam di Indonesia, (Jakarta: Kencana, 2008), h. 161

${ }^{5}$ Moh. Uzer Usman, Menjadi Pendidik Profesional, (Bandung: Remaja Rosdakarya, 2001), h.15

${ }^{6}$ Kunandar, Pendidik Profesional Implementasi Kurikulum Tingkat Satuan Pendidikan (KTSP) dan Sukses dalam Sertifikasi Pendidik, (Jakarta: Raja Grafindo Persada, 2007), h. 49

${ }^{7}$ Hamzah B. Uno, Profesi Kependidikan; Problema, Solusi dan Reformasi Pendidikan di Indonesia, (Jakarta: Bumi Aksara, 2008), h. 18

${ }^{8}$ Muhibbin Syah, et al, Metode Penelitian Agama dan Dinamika Sosial, (Jakarta: PT. Raja Grafindo Persada, 2002), h. 159
} 
membentuk profesionalisme pendidik salah satunya adalah dengan memberikan kewenangan bagi pendidik untuk bertanggung jawab penuh atas segala aspek pelaksanaan tugasnya. Pendidik harus diberikan kebebasan untuk mengambil keputusan secara mandiri. ${ }^{9}$ Pendidik yang diberikan kebebasan dalam mengembangkan kegiatan pembelajarannya dan bertanggung jawab penuh atas kegiatan dan kualitas pembelajaran tentu akan dapat membuat pendidik untuk selalu meningkatkan profesionalitasnya.

Untuk menumbuhkan dan meningkatkan kinerja pendidik tidak hanya dipengaruhi oleh faktor dalam diri pendidik tersebut. Akan tetapi juga dipengaruhi faktor di luar diri pendidik, di antaranya adalah faktor kepemimpinan kepala sekolah. Tanpa adanya dukungan, motivasi dan bantuan dari pihak-pihak yang terkait dalam sekolah tersebut pendidik akan mengalami kesulitan dalam meningkatkan kinerjanya. Untuk itu perlu adanya peran serta semua unsur yang ada dalam sekolah tersebut. Salah satu unsur yang penting dalam struktur sekolah yaitu kepala sekolah, dimana kepala sekolah merupakan pemimpin yang bertanggung jawab atas jalannya sistem pendidikan di sekolahnya. Sejarah pertumbuhan peradaban manusia banyak menunjukkan bukti bahwa salah satu faktor yang menentukan keberhasilan dan keberlangsungan organisasi adalah kuat tidaknya kepemimpinan. Kegagalan dan keberhasilan suatu organisasi banyak ditentukan oleh pemimpin karena pemimpin merupakan pengendali dan penentu arah yang hendak ditempuh oleh organisasi menuju tujuan yang akan dicapai.

Hal ini sejalan dengan apa yang dikemukakan oleh Siagian bahwa arah yang hendak ditempuh oleh organisasi menuju tujuan harus sedemikian rupa sehingga mengoptimalkan pemanfaatan dari segala sarana dan prasarana yang tersedia. Arah yang dimaksud tertuang dalam strategi dan taktik yang disusun dan dijalankan oleh organisasi bersangkutan. Perumusan serta penentu strategi dan taktik adalah pimpinan dalam organisasi tersebut. ${ }^{10}$

Semakin tinggi kepemimpinan yang diduduki seseorang dalam organisasi, nilai dan bobot strategi dari kebijakan yang diambilnya semakin besar. Sebaliknya, semakin rendah kedudukan seseorang dalam organisasi, kebijakan yang diambilnya pun lebih mengarah kepada hal-hal yang lebih operasional. Begitu juga di sekolah, kepala sekolah sebagai pemimpin di sekolah tersebut memiliki kedudukan dan peranan yang sangat penting dalam mengelola sekolah serta unsur-unsur yang ada di dalamnya melalui berbagai kebijakan yang dibuatnya, sehingga apat berjalan dan digunakan seoptimal mungkin dalam upaya mencapai tujuan pendidikan.

Agar kebijakan yang ditetapkan kepala sekolah mampu meningkatkan kinerja para pendidiknya, maka dalam pelaksanaan penentuan kebijakan tersebut haruslah berdasarkan prinsip Pembuat kebijakan tidak mendasarkan kebijakannya hanya atas petunjuk orang lain atau seseorang. ${ }^{11}$

Pendapat lainnya menyebutkan menurut Danim kebijakan kepala sekolah yang baik memiliki ciri-ciri sebagai Kebijakan sekolah yang telah diambil dan dirasakan tidak cocok lagi, tidak dipaksakan untuk dilaksanakan, tetapi harus dibuat kebiajakan pengganti. ${ }^{12}$

Apabila kebijakan kepala sekolah dibuat dan dilaksanakan sesuai dengan prinsip-prinsip di atas, maka akan mampu meningkatkan kinerja para pendidiknya, sebagaimana yang dikemukakan Mujamil Qomar, kebijakan kepala sekolah akan memperngaruhi dinamika pendidik-pendidik dalam berinisiatif, mengkreasikan sesuatu, atau menciptakan ide-ide baru. ${ }^{13}$ E. Mulyasa juga menegaskan bahwa kepala sekolah yang berani membuat kebijakan baru akan memotivasi pendidik untuk berperan aktif dalam perubahan tersebut. ${ }^{14}$

\footnotetext{
${ }_{9}^{9}$ Syafruddin Nurdin dan Basyuruddin Usman, Op. Cit., h. 22

${ }^{10}$ Sondang P. Siagian. Manajemen Strategik. (Jakarta: Bumi Aksara. 1994). h. 49

${ }^{11}$ Engkoswara dan Aan Komariah. Administrasi Pendidikan. (Bandung: Alfabeta. 2011). H. 110

${ }^{12}$ Sudarwan Danim. Visi Baru Manajemen Sekolah dari Unit Birokrasi ke Lembaga Akademik. (Jakarta: Bumi Aksara. 2006), h. 244

${ }^{13}$ Mujamil Qomar. Manajemen Pendidikan Islam. (Jakarta: Erlangga. 2007)., h. 288

14 E. Mulayas. 2002. Manajemen Berbasis Sekolah; Konsep, Strategi, dan Implementasi. (Bandung: Remaja Rosdakarya. 2002)., h. 181
} 
Pentingnya sebuah kebijakan dalam kepemimpinan ditegaskan dalam al-Qur ${ }^{\text {ee }}$ an dalam surat Ali Imran ayat 159 berikut ini:

Maka disebabkan rahmat dari Allah-lah kamu Berlaku lemah lembut terhadap mereka. Sekiranya kamu bersikap keras lagi berhati kasar, tentulah mereka menjauhkan diri dari sekelilingmu. karena itu ma'afkanlah mereka, mohonkanlah ampun bagi mereka, dan bermusyawaratlah dengan mereka dalam urusan itu. kemudian apabila kamu telah membulatkan tekad, Maka bertawakkallah kepada Allah. Sesungguhnya Allah menyukai orang-orang yang bertawakkal kepada-Nya. ${ }^{15}$

Dalam pengambilan kebijakan sebagai bentuk keputusan harus dilakukan dengan hati-hati dan tepat agar berjalan dengan baik, sebab apabila kebijakan salah akibatnya luas. Pengaruhnya terutama terhadap proses pembelajaran ataupun kualitas kerja para pendidik. Olehnya itu Kepala Sekolah tidak boleh behati kasar dan bersikap terlalu keras tetapi harus berhati lemah lembut sebelum mengambil keputusan atau menetapkan kebijakan hendaknya memiliki informasi tentang apa yang akan diputuskan, sehingga keputusan tersebut dapat mempengaruhi pendidik bukan semakin jauh dan tidak akan melaksanakan keputusan tersebut.

Berdasarkan beberapa pendapat tersebut dipahami bahwa kebijakan kepala sekolah yang tegas, bersifat demokratis, adil dan fkeksibel akan mampu meningkatkan semangat kerja para pendidik dan pegawai lainnya.

Faktor lainnya yang mempengaruhi kinerja pendidik adalah motivasi kepala sekolah. Menurut Burhanuddin, motivasi kepala sekolah adalah usaha pemberian dorongan kepada pendidik, agar mau bertindak dengan cara-cara yang diinginkan dalam mencapai tujuan yang ditentukan. ${ }^{16}$

Dengan memberikan motivasi yang demikian kepada para pendidik akan mampu meningkatkan kinerj para pendidiknya, sebagaimana yang dikemukakan Husaini Usman, motivasi sangat penting bagi manajer untuk meningkatkan kinerja bawahannya karena kinerja tergantung dari motivasi, kemampuan dan lingkungannya. ${ }^{17}$ Pendapat yang sama dikemukakan Engkoswara, bahwa motivasi diperlukan untuk memelihara semangat dan bahkan meningkatkan semangat kerja pegawai sehingga organisasi dapat mencapai tujuan secara produktif. ${ }^{18}$ Berdasarkan uraian tersebut dipahami bahwa kebijakan dan motivasi kepala sekolah kepada para pendidiknya akan mampu meningkatkan kinerja para pendidiknya untuk dapat melaksanakan tugas dan tanggung jawab dengan lebih baik.

\section{METHOD}

Jenis penelitian ini adalah penelitian lapangan atau Field Research, yaitu penelitian lapangan bermakna mempelajari secara intensif tentang latar belakang keadaan sekarang, dan interaksi sosial, individu, kelompok, lembaga dan masyarakat. ${ }^{19}$ Adapun lokasi penelitian yang dipilih adalah SMP Negeri 1 Pacet dan akan mencoba mencari data mengenai kepemimpinan kepala SMP Negeri 1 Pacet.

Dilihat dari sifatnya penelitian ini bersifat deskriptif analisis yaitu suatu penelitian untuk mengetahui perkembangan terjadinya suatu aspek fenomena sosial tertentu untuk mendeskripsikan secara terperinci fenomena tertentu. ${ }^{20}$ Penelitian deskriptif ini dipergunakan untuk menggambarkan kehidupan/keadaan kepala sekolah dan pendidik SMP Negeri 1 Pacet yang diteliti yaitu dengan menggunakan data yang sebenarnya.

${ }^{15}$ Depertemen RI, Al-Qur'an dan Terjemahannya, (Bandung: A-JRT, 2005) h. 55

${ }^{16}$ Burhanuddin. Analisis Adminsitrasi Manajemen dan Kepemimpinan Pendidikan. (Jakarta: Bumi Aksara. 1994)., h. 230

${ }^{17}$ Husaini Usman. Manajemen Teori, Praktek, dan Riset Pendidikan. (Jakarta: Bumi Aksara. 2006)., h. 223

${ }^{18}$ Engkoswara dan Aan Komariah. Op.cit., h. 218

${ }^{19}$ Masri Sinagarimbun dan Sofian Efendi, Metode Penelitian Survey, (Jakarta, Penerbit LP3ES, 1982), h.4 ${ }^{20} \mathrm{Ibid}$, h. 6 
Jenis data dan sumber data ini diperoleh peneliti dari bermacam-macam bentuk dan cara, adapun jenis data dalam penelitian ini penulis kelompokan menjadi dua bagian yaitu:

a. Jenis Data Primer. kebijakan kepala sekolah terhadap kinerja pendidik, dan yang menjadi sasaran pokoknya adalah : Kepala sekolah, dan pendidik.

b. Data sekunder. Data sekunder adalah data yang menyangkut data komite sekolah, lingkungan sekolah, serana dan prasarana, buku-buku sebagai sumber landasan pada fariabel yang akan dibahas, dan keterangan- keterangan lain yang tertulis maupun yang tidak tertulis yang berfungsi untuk kelengkapan data-data penelitian.

Apabila peneliti menggunakan dokumentasi, maka dokumen atau catatanlah yang menjadi sumber data, sedangkan yang dimaksud isi catatan adalah obyek penelitian. ${ }^{21}$ Sumber data dalam penelitian ini, adalah sebagai berikut :

a. Kepala Sekolah, Tenaga Kependidikan dan Komite

Kepala Sekolah, staf TU, penpendidiks yayasan dan komite sebagai informen untuk mendapatkan informasi yang berkenaan dengan kebijakan kepala sekolah terhadap kinerja pendidik, dan peran kepala sekolah sebagai motivator dalam upaya meningkatkan profesionalisme kinerja pendidik di SMP Negeri 1 Pacet

b. Pendidik

Cara pengambilan data dengan menggunakan teknik purposive sampling, yaitu penentuan sampel dengan pertimbangan tertentu. Pertimbangan tertentu ini adalah orang yang dianggap paling tahu tentang apa yang diharapkan. Purposive sampling penulis anggap yang paling cocok digunakan untuk penelitian kualitatif. ${ }^{22}$

Dengan demikian sumber data ini adalah pendidik dan kepala sekolah yang diambil hanya sebagian saja, yaitu: pendidik dan kepala sekolah dengan tujuan untuk mengambil data yang berkaitan dengan kebijakan kepala sekolah terhadap kinerja pendidik, dan peran kepala sekolah sebagai motivator dalam upaya meningkatkan profesionalisme kinerja pendidik di SMP Negeri 1 Pacet

Metode pengumpulan data agar dapat menghasilkan data yang cukup maksimal penulis menggunakan beberapa metode sebagai berikut :

Metode wawancara (interview) adalah : proses tanya jawab lisan dimana dua orang atau lebih berhadap-hadapan secara fisik yang satu dapat melihat muka yang lain dan mendengarkan dengan telinga masing-masing. ${ }^{23}$

Penulis menggunakan metode interview karena ingin memperoleh data yang langsung dari subyek yang di teliti sehingga penulis memperoleh data yang objektif dari data yang primer. Dalam penelitian ini digunakan metode interview bebas terpimpin, yaitu mengadakan wawancara bebas, namun tidak terlepas dari masalah yang diteliti, namun hal ini juga peneliti berpegang pada kerangka pertanyaan atau pedoman wawancara sebagai alat interview yang sudah dipersiapkan sesuai dengan permasalahan.

Teknik observasi adalah "pengamatan dan pencatatan dengan sistematis berdasarkan fenomena-fenomena yang akan diselidiki". Dalam arti luas, sebenarnya observasi tidak hanya terbatas pada pengamatan yang dilakukan secara langsung. ${ }^{24}$

Berbeda dengan pendapat Sutrisno Hadi "Observasi adalah pengamatan dan pencatatan secara sistematis tentang fenomena-fenomena yang diselidiki" 25 Jadi yang penulis amati adalah kebijakan kepala sekolah terhadap kinerja pendidik, dan peran kepala sekolah sebagai motivator dalam upaya meningkatkan profesionalisme kinerja pendidik di SMP Negeri 1 Pacet.

\footnotetext{
21 Suharsimi Arikunto, Prosedur Penelitian, (Jakarta, Bina Aksara, 1986), h. 102

${ }^{22}$ Ibid, Suharsimi Arikunto, h. 113

${ }^{23}$ Ibid, h. 192

${ }^{24}$ Suharsimi Arikunto, Metode Research II, (Yogyakarta, Yayasan Penerbit Fakultas Psikologi UGM, 1986), h.

${ }^{25}$ Sutrisno Hadi, Metodelogi Research Jilid II, (Yogyakarta, Andi Offset, 1987), h. 136
} 
Menurut Winarno Surahmat dokumentasi adalah metode yang digunakan dengan cara mengumpulkan data dengan cara melihat atau mencataat data yang telah tersedia. ${ }^{26}$

Metode dokumentasi penulis gunakan untuk mengumpulkan dan mengetahui data tentang kebijakan kepala sekolah terhadap kinerja pendidik, dan peran kepala sekolah sebagai motivator dalam upaya meningkatkan profesionalisme kinerja pendidik di SMP Negeri 1 Pacet.

Analisa data dimaksud disini adalah penganalisaan terhadap objek ilmiah dalam hal ini kepala sekolah, dan para pendidik, kebijakan kepala sekolah terhadap kinerja pendidik, dan peran kepala sekolah sebagai motivator dalam upaya meningkatkan profesionalisme kinerja pendidik di SMP Negeri 1 Pacet. Dengan jalan memilah-milah antara data satu dengan data lainnya sebagai upaya untuk memperoleh kejelasan. Dalam penulisan tesis ini analisa yang digunakan adalah analisa kualitatif, karena data yang dibutuhkan dikumpulkan dengan cara diklasifikasikan yang berwujud kasus-kasus, sehingga dapat disusun klasifikatoris. ${ }^{27}$

Dalam penelitian ini digunakan analisa secara kualitatif terhadap fokus penelitian yang dikaji yaitu bagaimana kebijakan kepala sekolah terhadap kinerja pendidik, dan peran kepala sekolah sebagai motivator dalam upaya meningkatkan profesionalisme kinerja pendidik di SMP Negeri 1 Pacet. Dengan menggunakan beberapa metode dan analisa di atas maka di harapkan penelitian ini dapat mencapai hasil yang maksimal sesuai dengan tujuan yang diharapkan dalam penelitian.

\section{HASIL DAN PEMBAHASAN}

\section{Result}

The main provisions in writing research or study findings are as follows: 1) present the research or study findings briefly, while still providing sufficient detail to support conclusions, 2 ) may use tables or pictures, but do not repeat the same information, by providing narration at the bottom of the table or picture so that the reader can understand the tables or pictures presented by the author, and 3) each research finding or study must be interpreted properly using standard spelling.

Adapun yang menjadi kendala dan pendukung dari pelaksanaan kebijakan kepala sekolah dalam peningkatan kompetensi pedagogik dan kompetensi kepribadian tersebut yaitu menurut hasil wawancara dengan kepala SMP Negeri 1 Pacet menyatakan bahwa: "Hambatan atau kendala dan pendukung dalam meningkatkan kinerja pendidik dalam penerapan kebijakan tersebut tentu ada hambatan atau kendala yaitu, belum sepenuhnya pendidik menyadari perlunya pengembangan SDM, banyaknya tugas-tugas yang menyita waktu, tenaga dan pikiran yang terkait langsung dengan program pengembangan SDM dan tentang penyesuaian jadwal kegiatan pada hari efektif'.

Adapun yang menjadi pendukung dari kebijakan kepala sekolah tersebut yaitu kepala sekolah lebih mengaktifkan pendidikk untuk mengikuti berbagai pelatihan, workshop, seminar, dan saya sebagai kepala SMP Negeri 1 Pacet juga memberikan sarana dan fasilitas kepada seluruh pendidik untuk membuat alat peraga pendidikan dan modul pembelajaran tujuannya untuk memudahkan pendidik dalam mengajar. ${ }^{28}$

Berdasarkan hasil wawancara dengan kepala sekolah sebagaimana yang telah di sampaikan tersebut, peneliti melakukan wawancara dengan Sukamto, salah satu pendidik SMP Negeri 1 Pacet, berpendapat bahwa: "Bagi saya hambatan atau kendala pelaksanaan kebijakan tersebut yaitu tentang penyesuaian jadwal kegiatan misalnya kegiatan KKG, seminar maupun pelatihan lainnya bertepatan dengan hari efektif sekolah, sehingga sebagian pendidik tidak mengikuti kegiatan tersebut supaya kegiatan belajar mengajar tidak terganggu. Adapun yang menjadi pendukung dari

\footnotetext{
${ }^{26}$ Winarno Surahmad, Dasar dan Tehnik Rieaserch, (Bandung, CV Targito, 1972), h. 125.

${ }^{27}$ Koentjoroningrat, Metode-metode Penelitian Masyarakat, (Jakarta, PT. Gramedia, 1985), h. 108

${ }^{28}$ Sugianto, Kepala Sekolah SMP Negeri 1 Pacet, Wawancara, 20 Maret 2018
} 
kebijakan tersebut kepala sekolah memberi ijin dan memfasilitasi kegiatan dengan memberikan surat tugas bagi pendidik yang mengikuti kegiatan tersebut". ${ }^{29}$

Demikian pula menurut Lenie, berpendapat bahwa: Yang menjadi kendala dan pendukung dalam meningkatkan kompetensi pedagogik dan kompetensi kepribadian pendidik dalam penerapan kebijakan tersebutyaitu,belum sepenuhnya pendidik menyadari perlunya pengembangan SDM, banyaknya tugas-tugas yang menyita waktu, tenaga dan pikiran yang terkait langsung dengan program pengembangan SDM dan tentang penyesuaian jadwal kegiatan pada hari efektif. Adapun yang menjadi pendukung dari kebijakan tersebut yaitu kepala sekolah lebih mengaktifkan pendidikk untuk mengikuti berbagai pelatihan, workshop, seminar, kepala SMP Negeri 1 Pacet juga memberikan sarana dan fasilitas kepada seluruh pendidik untuk membuat alat peraga pendidikan dan modul pembelajaran tujuannya untuk memudahkan pendidik dalam mengajar. $^{30}$

Selanjutnya hasil wawancara dengan Irwansyah Putra mengenai faktor penghambat dan faktor pendukung kebijakan kepemimpinan kepala sekolah sebagai berikut: "Menurut saya faktor penghambat dan pendukung pelaksanaan kebijakan tersebut yaitu tentang penyesuaian jadwal kegiatan misalnya kegiatan KKG, seminar maupun pelatihan lainnya bertepatan dengan hari efektif sekolah, kurang lengkapnya sarana prasarana seperti minimnya buku paket dan ruang perpustakaan kurang mendukung. Sedangkan faktor pendukung pelaksanaan kebijakan adalah dukungan dari semua pendidikk yang lain yaitu rasa kekeluargaan antara warga sekolah. ${ }^{31}$

Untuk memperkuat hasil wawancara peneliti melakukan observasi di SMP Negeri 1 Pacet bahwa kendala yang dihadapi kepala sekolah dalam meningkatkan kompetensi pedagogik dan kepribadian pendidik yaitu disebabkan belum sepenuhnya pendidik menyadari perlunya pengembangan peningkatan kompetensi pendidik, kurangnya sarana prasarana seperti minimnya buku paket, banyaknya tugas-tugas pendidik dan tentang jadwal hari efektif bersamaan dengan kegiatan KKG, seminar maupun pelatihan lainnya.

Adapun yang menjadi pendukung dari kebijakan tersebut yaitu kepala sekolah lebih mengaktifkan pendidikk untuk mengikuti berbagai pelatihan, workshop, seminar, kepala SMP Negeri 1 Pacet juga memberikan sarana dan fasilitas kepada seluruh pendidik untuk membuat alat peraga pendidikan dan modul pembelajaran tujuannya untuk memudahkan pendidik dalam mengajar. Dan dari penjelasan kepala SMP Negeri 1 Pacet, faktor yang menghambat proses pelaksanaan kebijakan dapat dibedakan menjadi 2 (dua) faktor, yaitu internal dan eksternal. Faktor internal adalah faktor yang berasal dari lembaga pedidikan itu sendiri (sekolah) dan faktor ekternal adalah faktor yang berasal dari luar lembaga pendidikan (sekolah). Faktor internal meliputi, pendidikk SMP Negeri 1 Pacet belum semuanya mengikuti pelatihan atau workshop tentang peningkatan kompetensi pendidik.

\section{KESIMPULAN}

The conclusion consists of a summary of the article that presents a summary of the results of research that has been carried out and is the answer to the formulation of the problem. Conclusions must be aligned with the formulation of the problem and research objectives. If the conclusion is more than one, then it's written using numbering numbers in paragraphs, not by using bullets, and the writer can also add the prospect of development of the results of the research or study as well as how to further implications will be the prospects of research or further research.

\footnotetext{
${ }^{29}$ Sukamto, Pendidik GTY/PTY Mata Pelajaran SMP Negeri 1 Pacet, Wawancara, 19 Maret 2018 Pukul 11.20

${ }^{30}$ Irwansyah Putra, Tenaga Administrasi Sekolah SMP Negeri 1 Pacet, Wawancara, 22 Maret 2018

${ }^{31}$ Irwansyah Putra, Tenaga Administrasi Sekolah SMP Negeri 1 Pacet, Wawancara, 22 Maret 2018
} 
Berdasarkan pendapat dan leteratur beberapa teori yang telak dikemukakan diatas atau babbab sebelumnya maka dapat disimpulkan bahwa peran kepala sekolah dalam meningkatkan kinerja pendidik professional sebagai berikut : Kebijakan yang dibuat oleh kepala SMP Negeri 1 Pacet dalam meningkatkan kinerja pendidik professional adalah dengan cara mengikutkan KKG workshop, pelatihan, aktif dalam kegiatan di sekolah baik yang diselenggarakan oleh Dinas Pendidikan Kota maupun LPMP. Sedangkan peningkatan kompetensi kepribadian pendidik yaitu bahwa dalam meningkatkan kedisiplinan pendidik, kepala sekolah didukung oleh pendidikpendidik.

Kebijakan yang telah di buat oleh kepala SMP Negeri 1 Pacet dalam upaya meningkatkan kinerja professional pendidik dengan cara mengoptimalkan peran kepala sekolah sebagai pemimpin yang meliputi: Sebagai pendidik (Educator), Sebagai manager, Sebagai administrator, Sebagai supervisor, Sebagai pemimpin (leader), Sebagai innovator, dan Peran kepala sekolah Sebagai menejemen kurikulum sebagaimana termaktub pada peraturan menteri pendidikan nasional nomor 13 tahun 2007 tentang standar Kepala sekolah /Madrasah, yaitu kompetensi Kepribadian, Menejerial, Kewirausahaan, supervisi, dan kompetensi social. Kendala kepala sekolah dalam meningkatkan kinerja professional pendidik adalah, banyaknya tugas-tugas yang menyita waktu, tenaga dan pikiran yang terkait langsung dengan program pengembangan SDM. Dan juga waktu kegiatan peningkatan profesionalisme pendidik bersamaan dengan kegiatan proses belajar mengajar berlangsung efektif sehingga pendidik tidak dapat mengikuti kegiatan tersebut dengan rutin.

\section{REFERENSI}

Abraham H. Maslow, 1970., Motivation and Personality, New York: Harper \& Row Publishers. Abu Ahmadi dan Nur Uhbiyati. 1991. Ilmu Pendidikan. Jakarta: Rineka Cipta.

Ali Muhammad Taufiq. 2004. Praktik Manajemen Berbasis Al-Quran. Jakarta: Gema Insani.

Anas Sudijono. 1997. Pengantar Statistik Pendidikan. Jakarta: Rajawali. Andrew B. Crider, et.al. 1983. Psychology. London: Foresman and Compeny. A. Samana. 1994. Profesionalisme Keguruan. Yogyakarta: Kanisius.

Bimo Walgito. 2004. Pengantar Psikologi Umum. Yogyakarta: Andi.

Burhanuddin. 1994. Analisis Adminsitrasi Manajemen dan Kepemimpinan Pendidikan. Jakarta: Bumi Aksara.

Departemen Pendidikan dan Kebudayaan. 1997. Kamus Besar Babasa Indonesia. Jakarta: Balai Pustaka.

Direktorat Pendidikan Luar Biasa, Pengadaan dan Pembinaan Tenaga Kependidikan dalam Pendidikan Iklusif, http://www.ditplb.or.id/ 13 Januari 2018

Djaali, 2007, Psikologi Pendidikan, Jakarta: Bumi Aksara.

Edi Kusnadi. 2005. Metodologi Penelitian. Jakarta: Ramayana.

Engkoswara dan Aan Komariah. 2011. Administrasi Pendidikan. Bandung: Alfabeta.

Ernest R. Hilgard, 1953, Introduction to Psychology, (New York: Harcourt, Brace and Company.

E. Mulayas. 2002. Manajemen Berbasis Sekolah; Konsep, Strategi, dan Implementasi. Bandung: Remaja Rosdakarya. 2003. Menjadi Kepala Sekolah Profesional dalam Konteks Menyukseskan MBS dan KBK. Bandung: Remaja Rosdakarya.

Greenberg. 1996. Managing Behaviors in Organizations. New York: Prentice Hall.

Hadari Nawawi. 1989, Administrasi Pendidikan. Jakarta: Haji Masagung. 1993. metode penelitian Bidang Sosial. Yogyakarta: Gajah Mada University Press.

Hamzah B. Uno. 2007. Teori Motivasi dan Pengukurannya: Analisis di Bidang Pendidikan. Jakarta: Bumi Aksara.

2004. Landasan Pembelajaran. Gorontalo: Nurul Jannah. 
2008. Profesi Kependidikan; Problema, Solusi dan Reformasi Pendidikan di Indonesia. Jakarta:

Bumi Aksara. Handoko, 2003, Manajemen. Edisi 2. Yokyakarta : BPFE.

Husaini Usman. 2006. Manajemen Teori, Praktek, dan Riset Pendidikan. Jakarta: Bumi Aksara.

HM. Sulthon Masyhudi, dkk. 2005. Manajemen Pondok Pesantren. Jakarta: Diva Pustaka.

Drummond. 1995. Pengambilan Keputusan yang Efektif. Jakarta: Gramedia.

Imron Arifin. 1998. Kepemimpinan Kepala Sekolah. Malang: Desertasi.

Jamal Madhi. 2002. Menjadi Pemimpin yang Efektif dan Berpengaruh. Bandung: Syaamil Cipta Media.

Jarmanto, Kepemimpinan Sebagai Ilmu dan Seni, Yogyakarta: Liberty, 1983

Jhon Whtimore. 1997. Coaching for Performance, Seni mengarabkan dan Mendongkrak Kinerja,

Terjemahan: Dwi Helly Purnomo dan Louis Novianto. Jakarta: Gramedia Pustaka Utama.

JJ. Litrell. 1984. From School to Work. A. Cooperative Education Book. South

Holland, Illinois: The Goodheart-Willcox Campany, Inc.

Lussier, Robert N. 2009, Management Fundamen-tals. Concepts-Applications- Skill Develoment.

Printed in the USA

Made Pidarta. 1995. Peranan Kepala Sekolah pada Pendidikan Dasar. Jakarta: Gramedia.

Marno dan Triyo Supriyatno. 2008. Manajemen dan Kepemimpinan Pendidikan Islam. Bandung:

Refika Aditama.

Masri Singarimbun dan Sofian Effendi (ed). 1989. Metode Penelitian Survey. Jakarta: LP3ES.

Muhibbin Syah. 1997. Psikologi Pendidikan dengan Pendekatan Baru. Bandung: Remaja Rosdakarya.

Mukhtar. 2003. Desain Pembelajaran Pendidikan Agama Islam. Jakarta: Misaka Galiza.

Mujamil Qomar. 2007. Manajemen Pendidikan Islam. Jakarta: Erlangga.

Mulyono. 2008. Manajemen Administrasi dan Organisasi Pendidikan. Yogjakarta: Ar-Ruuz.

M. Ngalim Purwanto. 2003. Administrasi dan Supervisi Pendidikan. Bandung: Remaja Rosdakarya.

Nana Sudjana. 1991. Tuntunan Penyusunan Karya Ilmiah. Bandung: Sinar Baru. Nanang Fattah. 2003. Landasan Manajemen Pendidikan. Bandung: Remaja Rosdakarya.

Nurkholis. 2006. Manajemen Berbasis Sekolah. Jakarta: Grasindo.

Oemar Hamalik. 2004. Pendidikan Guru Berdasarkan Pendekatan Kompetensi. Jakarta: Bumi Aksara.

Oteng Sutisna, Administrasi Pendidikan Dasar Teoritis untuk Praktek Profesional, Bandung: Angkasa, 2007

Paul Suparno. 2005. Guru Demokratis di Era Reformasi. Jakarta: Grasindo.

Piet A. Sahertian dan Ida Aleida Sahertian. 1992. Supervisi Pendidikan. Jakarta: Rineka Cipta.

Robbins, S.P. 1998., Perilaku Organisasi, Konsep, Kontroversi, Aplikasi. Jakarta: Prenhallindo.

Ruben D. Brent, 1992, Communication and Human Behavior $3^{\text {rd }}$, New Jersey: Prentice Hall.

Rivai. 2005. Performance Apraisal: Sistem yang tepat untuk menilai kinerja karyawan dan meningkatkan daya saing perusahaan. Jakarta: Raja Grafindo Persada.

Sambas Ali Muhidin dan Maman Abdurrahman. 2007. Analisis Korelasi, Regresi, dan Jalur dalam Penelitian. Bandung: Pustaka Setia.

Sardiman AM. 1986. Dasar-Dasar Kompetensi. Jakarta: Rajawali.

Sofian Efendi dan Chris Manning. 1999. Prinsip-Prinsip Analisa Dara: Metode Penelitian Survey. Jakarta: Tema Baru.

Sofyan Syafri Harahap. 1996. Manajemen Kontemporer. Jakarta: Rajawali, Press. Sondang P. Siagian. 1994. Manajemen Strategik. Jakarta: Bumi Aksara.

Stephen J. Kenezevich. 1984. Administration of Public Education. New York: Harper Collins Publisher.

Sudarwan Danim. 2006. Visi Baru Manajemen Sekolah dari Unit Birokrasi ke Lembaga Akademik. Jakarta: Bumi Aksara.

Sumadi Suryabrata. 1995. Psikologi Pendidikan. Jakarta: Rajawali. Sufyarma. 2004. Kapita Selekta Manajemen Pendidikan. Bandung: Alfabeta. 
Sugiyono. 2008. Metode Penelitian Pendidikan Pendekatan Kuantitaif, Kualitatif dan R\&D. Bandung: Alfabeta.

Suharsimi Arikunto. 1989. Prosedur Penelitian. Jakarta: Bina Aksara.

Sutrisno Hadi. 1985. Metodologi Research. Yogyakarta: Fakultas Psikologi UGM.

1983. Metodologi Research Jilid II. Yogyakarta: Yayasan Tasbit Fakultas Psikologi.

Syafaruddin. 2005. Manajemen Lembaga Pendidikan Islam. Jakarta: Ciputat Press.

Syafruddin Nurdin dkk,. 2002. Guru Profesional \& Implementasi Kurikulum. Jakarta: Ciputat Press.

Syaiful Sagala. 2007. Manajemen Strategik dalam Peningkatan Mutu Pendidikan. Bandung: Alfabeta.

S. Margono. 2004. Metodologi Penelitian Pendidikan. Jakarta: PT.Rineka Cipta.

Tayar Yusuf dan Syaiful Anwar. 1997. Metodologi Pengajaran Agama dan Bahasa Arab. Jakarta: Raja Grafindo Persada.

Wiludjeng. 2007, Pengantar Manajemen. Yokyakarta: Graha Ilmu

Winarno Surahman. 1982. Pengantar Penelitian Ilmiah. Bandung: Tarsito. 